\title{
Relações internacionais do Brasil: um balanço da era Cardoso
}

\author{
AMADO LUIZ CERVO*
}

\section{Introdução}

O triunfo do capitalismo sobre o socialismo soviético em 1989 deu impulso à globalização em sua dimensão horizontal e vertical. Três fatores influíram sobre o reordenamento das relações internacionais: a ideologia neoliberal, a supremacia do mercado e a superioridade militar dos Estados Unidos. A globalização engendrou nova realidade econômica caracterizada pelo aumento do volume e da velocidade dos fluxos financeiros internacionais, pelo nivelamento comercial em termos de oferta e demanda, pela convergência de processos produtivos e, enfim, pela convergência de regulações nos Estados.

Essa tendência histórica deparou-se, entretanto, com duas outras, uma que a continha e outra que a embalava: a formação de blocos econômicos e a nova assimetria entre o centro do capitalismo e sua periferia.

Diante desse cenário internacional, a política exterior do Brasil adaptou-se de modo não simples. À primeira vista, parece haver-se perdido o rumo que por sessenta anos havia impresso racionalidade e continuidade à política exterior de um Estado que buscava obstinadamente a promoção do desenvolvimento nacional. O Itamaraty teve dificuldades de reagir. Entre 1990 e 1995, cinco ministros ocuparam a pasta das Relações Exteriores, dois de fora da casa, a denotar instabilidade de pensamento e de estratégia externa. O processo que resultou na cassação do mandato do Presidente Fernando Collor de Melo (1990-92) em 1992 e o hiato do Governo de Itamar Franco até 1994 contribuíram para tal indefinição. A partir de 1995, com os dois mandatos de Fernando Henrique Cardoso (1995-2002) e a continuidade da gestão do Chanceler Luiz Felipe Lampreia (1995-2000), pretendeuse imprimir coerência à ação externa. Não sem reações e tropeços. Havia no Itamaraty quem lançasse dúvidas sobre o rumo tomado. O pensamento crítico que emergiu com força durante o Governo de Itamar Franco prosseguiu nas manifestações de Rubens Ricupero, Celso Amorim, Luiz Felipe de Seixas Correa e outros embaixadores, mas ninguém o formulou de modo tão incisivo quanto o

Rev. Bras. Polít. Int. 45 (1): 5-35 [2002]

* Professor Titular de História das Relações Internacionais da Universidade de Brasília. A publicação desse texto, parte da História da Política Exterior do Brasil (Brasília: EdUnB, 2002) foi autorizada pela Editora Universidade de Brasília. 
Diretor do Instituto de Pesquisa de Relações Internacionais da própria casa, Embaixador Samuel Pinheiro Guimarães.

\section{A dança dos paradigmas}

O pensamento político brasileiro aplicado às relações internacionais do Brasil desde 1990 não foi homogêneo, como ocorreu no seio da comunidade epistêmica argentina que assessorou o Presidente Carlos Saúl Menem, durante seus dois mandatos. Ante a instabilidade do Itamaraty na primeira metade da década, acabou por prevalecer o pensamento de Fernando Henrique Cardoso, que fora Ministro das Relações Exteriores entre outubro de 1992 e maio de 1993 e que contou depois por seis anos com Lampreia, seu fiel intérprete. A passagem por duas ocasiões pelo Itamaraty do Ministro Celso Lafer, de forte pensamento próprio, reforçou a linha de pensamento e ação de Cardoso.

Além de haver-se enfraquecido em razão da discordância interna e da prevalência de pensamento externo à casa, o processo decisório em política exterior do Itamaraty perdeu força sob outro ângulo também, na medida em que as decisões nas áreas da alfândega, das finanças externas e da abertura empresarial foram deslocadas para as autoridades econômicas, que aplicavam diretrizes monetaristas e liberais com desenvoltura e com conseqüências sobre a organização nacional.

Em virtude de tais contingências, o Brasil imprimiu desde 1990 orientações confusas, até mesmo contraditórias, à política exterior. Identificamos três linhas de força da ação externa que definimos com auxílio do conceito de paradigma: o Estado desenvolvimentista, o Estado normal e o Estado logístico. A coexistência de paradigmas, inadmissível nas ciências exatas e naturais, embora paradoxal, é possível nas ciências humanas e sociais, onde eles adquirem a função metodológica de organizar a matéria e de dar-lhe inteligibilidade orgânica mediante uma visão compreensiva dos fatos.

O Estado desenvolvimentista, de caraterísticas tradicionais, reforça o aspecto nacional e autônomo da política exterior. Trata-se do Estado empresário que arrasta a sociedade no caminho do desenvolvimento nacional mediante a superação de dependências econômicas estruturais e a autonomia de segurança. O Estado normal, invenção latino-americana dos anos noventa, foi assim denominado pelo expoente da comunidade epistêmica argentina, Domingo Cavallo, em 1991, quando era Ministro das Relações Exteriores do Governo de Menem. Aspiraram ser normais os governos latino-americanos que se instalaram em 198990 na Argentina, Brasil, Peru, Venezuela, México e outros países menores. A experiência de mais de uma década revela que esse paradigma envolve três parâmetros de conduta: como Estado subserviente, submete-se às coerções do centro hegemônico do capitalismo; como Estado destrutivo, dissolve e aliena o núcleo central robusto da economia nacional e transfere renda ao exterior; como 
Estado regressivo, reserva para a nação as funções da infância social. O terceiro é o paradigma do Estado logístico que fortalece o núcleo nacional, transferindo à sociedade responsabilidades empreendedoras e ajudando-a a operar no exterior, por modo a equilibrar os benefícios da interdependência mediante um tipo de inserção madura no mundo globalizado.

O primeiro paradigma, cujo protótipo na América Latina foi o Brasil, entre 1930 e 1989, elevou este país ao mais alto nível de desenvolvimento regional; o segundo, cujo protótipo foi a Argentina da era Menem, conduziu à crise de 20012002, caracterizada pelo aprofundamento de dependências estruturais e pelo empobrecimento da nação; o terceiro, cujo protótipo foi o Chile, garante uma inserção internacional madura. Os países da América Latina avançaram mais ou menos esses caminhos, com maior ou menor coerência, mas apenas o Brasil percorreu os três, como um carro que houvesse desligado os faróis à noite e adentrasse pelo escuro à procura de seu destino.

A indefinição oriunda da coexistência paradigmática da política exterior brasileira desde 1990 levou à agonia do Estado desenvolvimentista, à emergência do Estado normal e ao ensaio de Estado logístico.

O desenvolvimento não desapareceu no horizonte da política exterior brasileira ao encerrar-se em 1989 o ciclo desenvolvimentista de sessenta anos. Deixou apenas de ser o elemento de sua racionalidade. A estratégia tradicional foi posta em dúvida porque se supunha que houvesse desembocado na crise do endividamento, da instabilidade monetária e da estagnação econômica dos anos oitenta, e que não resistiria diante das transformações da ordem global ao término da Guerra Fria.

Segundo o Chanceler Celso Amorim, o objetivo síntese do desenvolvimento manteve-se, contudo, presente nos esforços do Brasil durante as negociações da Rodada Uruguai do GATT, na criação do Mercosul, na proposta de criação da ALCSA (Área de Livre Comércio Sul-Americana), no fato de haver o Brasil relançado o tema do desenvolvimento sobre os foros multilaterais quando andava ofuscado pelo radicalismo neoliberal global. Itamar Franco deixou claro que o desenvolvimento prosseguia sendo “o objetivo maior da política externa”. Depois dele, Cardoso também denunciou a retirada do tema do grande debate internacional, em razão da extinção do diálogo norte-sul, bem como os obstáculos erigidos posteriormente pela globalização aos esforços de desenvolvimento. A realização da Conferência de Cúpula sobre o Desenvolvimento Social (Copenhage, 1995) foi considerada uma vitória brasileira. A diplomacia brasileira requisitou uma relação entre desenvolvimento e temas globais para o desenho da ordem internacional. Não aceitou, durante a Conferência sobre Meio Ambiente e Desenvolvimento (Rio de Janeiro, 1992) que as preocupações com a ecologia sacrificassem o curso do desenvolvimento, vinculou-o à fruição dos direitos humanos durante a Conferência Mundial sobre Direitos Humanos de Viena, em 1993, e, sobretudo, 
agiu no GATT, e depois na OMC, para alcançar uma regulamentação do sistema multilateral de comércio que evitasse resultados favoráveis apenas às nações avançadas.

A emergência do Estado normal - subserviente, destrutivo e regressivo nas estratégias de relações internacionais do Brasil teve como impulso conceitual a idéia de mudança. Não se trata de uma leviandade mental, mas de uma convicção profundamente arraigada na mentalidade de dirigentes brasileiros, capaz de provocar: a) o revisionismo histórico e a condenação das estratégias internacionais do passado; b) a adoção acrítica de uma ideologia imposta pelos centros hegemônicos de poder; c) a eliminação das idéias de projeto e de interesse nacionais; d) a correção do movimento da diplomacia. Sob este paradigma, a política exterior do Brasil orientouse por um equívoco de substância, que Fernando Henrique Cardoso expressou em artigo para a Revista Brasileira de Política Internacional em 2001: uma tríplice mudança interna - democracia, estabilidade monetária e abertura econômica eram seus novos comandos. Como não se conhecem experiências em que estes comandos tenham servido a Estados maduros como vetores de política exterior, a idéia de mudança introduziu naturalmente o paradigma do Estado normal, como invenção da inteligência periférica.

Desistindo de fazer política internacional própria, o Brasil aplicou as duas gerações de reformas sugeridas pelo chamado Consenso de Washington. Em uma primeira fase, implementou políticas de rigidez fiscal, retirou o Estado dos investimentos produtivos, contraiu salários e benefícios do Estado do bem-estar, privatizou empresas públicas, vendeu-as às companhias estrangeiras para arrecadar dólares e pagar a dívida externa. Pôs em marcha, depois, reformas de segunda geração, buscando estrutura regulatória estável e transparência dos gastos públicos, sobretudo criando facilidades para o empreendimento estrangeiro penetrar a atividade econômica. As duas ondas de reformas exigidas da América Latina pelos Estados Unidos e pelos órgãos financeiros internacionais, Banco Mundial e FMI, denominadas de boa governabilidade, deveriam resultar em regras e instituições favoráveis à expansão das empresas privadas transnacionais na região. A subserviência do Estado normal, erigida como ideologia da mudança, engendrou graves incoerências, ao confundir democracia com imperialismo de mercado, competitividade com abertura econômica e desenvolvimento com estabilidade monetária. Completou-se com o desmonte da segurança nacional e a adesão a todos os atos de renúncia à construção de potência dissuasória.

Na vigência dessas novas condições políticas, o Estado normal encaminhou no Brasil a destruição do patrimônio e do poder nacionais. Utilizou conscientemente os mecanismos das privatizações para transferir ativos nacionais a empresas estrangeiras, abrindo desse modo nova via de transferência de renda ao exterior por meio dos lucros e aprofundando a dependência estrutural da nação. Sujeitouse à especulação financeira internacional que também absorveu renda interna. 
Mais de oitenta bilhões de dólares arrecadados pelas privatizações brasileiras foram gastos em despesas de custeio, sem benefício algum para o reforço de setores estratégicos da economia nacional. Como as empresas traziam de fora equipamentos sofisticados e não se voltavam para as exportações, apenas para o vasto mercado brasileiro, o país tornava inócua sua política de comércio exterior. A ação destrutiva do Estado normal priva, ademais, o governo de meios de poder sobre a arena internacional.

A terceira dimensão do paradigma do Estado normal é o salto para trás que imprime ao processo histórico. As atividades empresariais em mãos de nacionais tendem a reduzir-se à montagem de produtos e à execução mecânica de serviços no seio de empresas, cujas matrizes localizadas no exterior criam a tecnologia. A alienação da Embratel, o coração do sistema brasileiro de comunicações, fechou escola de aprendizagem e aplicação de conhecimentos na área. Nesse e em outros domínios, a capacitação da inteligência brasileira, que havia alcançado níveis de primeiro mundo e amplitude social em alguns setores, tende a tornar-se inútil e ociosa. Tanto assim é que o Ministro da Ciência e Tecnologia, Ronaldo Sardenberg, propôs em 2001 ao Conselho Nacional de Desenvolvimento Científico e Tecnológico (CNPq) um plano de fixação de doutores brasileiros no Brasil. Como aproveitálos, se o Estado normal empurrava a economia de regresso aos domínios das atividades primárias, onde se manteve desde a Independência até o advento de Getúlio Vargas?

A racionalidade histórica demandava, pois, ao termo do ciclo desenvolvimentista em 1989, não o paradigma do Estado normal, que impregnou as políticas públicas de Fernando Henrique Cardoso, mas outro esquema de ação, que chamamos de Estado logístico, também presente nas decisões desse homem de Estado, por feliz incoerência. O Estado logístico teve como desafios absorver, no ponto de transição, as forças nacionais geradas pelo Estado desenvolvimentista e engendrar a inserção madura no mundo unificado pelo triunfo do capitalismo. Onde se pode perceber a ação logística do Estado brasileiro desde 1990?

O caminho do Estado logístico levou o país a controlar o processo de privatização para evitar o risco de consumar a destruição do patrimônio nacional a cargo do Estado normal, como levou-o à criação de algumas grandes empresas de matriz brasileira em setores em que a competitividade sistêmica era possível, como a mineração, a siderurgia, a indústria aeronáutica e espacial. Para tanto, a abertura haveria de ser dosada pela capacidade de adaptação do empresariado local. A diplomacia empresarial chamou as associações de empresários e de trabalhadores e as lideranças de outros segmentos da sociedade organizada para auscultar seus interesses na fixação do grau de abertura e nas opções diante da formação de blocos econômicos e das negociações entre o Mercosul e outros blocos. Lançouse, desse modo, o conceito de América do Sul como área de fortalecimento prévio das economias regionais sob liderança brasileira. Estribada na credibilidade que o 
país alcançou com a consolidação da democracia, a estabilidade e a abertura econômicas, a diplomacia presidencial foi acionada com vigor nos foros multilaterais e nas relações bilaterais. Denunciou os ganhos unilaterais da interdependência que se estabeleceu entre o centro hegemônico e o Estado normal da periferia. Assim, o ensaio de Estado logístico, uma assimilação do comportamento dos grandes pelo governo brasileiro, recuperou estratégias de desenvolvimento e conferiu à política exterior funções assertivas: a) o reforço da capacidade empresarial do país; b) a aplicação da ciência e da tecnologia assimiladas; c) a abertura dos mercados do norte em contrapartida ao nacional; d) mecanismos de proteção diante de capitais especulativos; e) uma política de defesa nacional.

$\mathrm{O}$ analista das relações internacionais do Brasil fica perplexo ante tal indefinição oriunda da coexistência dos paradigmas, porque não dispõe de apenas uma categoria conceitual - uma teoria, dirá o politólogo - para dar inteligibilidade orgânica aos fatos, como ocorria anteriormente com o paradigma desenvolvimentista. Enfrenta o desafio de medir o comprimento do caminho percorrido pelos governos brasileiros desde 1990, rumo à consolidação do desenvolvimento e à inserção madura no mundo da globalização ou de regresso à infância social e à dependência estrutural. Os políticos também ficaram perplexos. Em agosto de 2001, os chefes de Estado reunidos em Santiago na 15 Cúpula do Grupo do Rio reconheceram que a América Latina havia implementado as reformas requeridas pelo centro sem que a globalização respondesse com benefícios para o desenvolvimento da região ${ }^{1}$.

\section{O Brasil diante das regras e estruturas da globalização}

\section{Multilateralismo e temas globais}

Como fazia há décadas, a diplomacia brasileira manteve forte presença nos órgãos multilaterais, desde 1990. No passado, esta presença tinha por escopo substituir a ordem, desde 1990 busca-se influir sobre a definição de seus parâmetros. O multilateralismo foi eleito como meio de ação da nação desprovida de poder para realizar sua vontade. A diplomacia brasileira voltou-se para os novos temas que compunham a agenda da globalização - aliás não eram novos mas renascidos da distorção que lhes imprimia a ordem bipolar. Com o fim da Guerra Fria, desapareceu a dicotomia entre alta e baixa política e a segurança estratégica incorporou sem distância o reordenamento econômico. A ascensão do livre comércio e do livre fluxo de capitais deprimiam a questão da segurança entre 1990 e 2001, quando o tema da governabilidade global ameaçava as soberanias nacionais. $\mathrm{O}$ Brasil ocupava-se então com liberalismo econômico, ecologia, direitos humanos, segurança, multilateralismo comercial e fluxos de capitais. Examinamos as três primeiras questões nesse parágrafo, as outras três a seguir. 
Liberalismo econômico. Durante as administrações de Collor de Melo e Cardoso, o neoliberalismo inspirou as políticas públicas internas e externas, situandoas no âmbito do Estado normal. Inspirou, ademais, as delegações do Brasil nas negociações do GATT e da OMC acerca de propriedade intelectual, investimentos, comércio de serviços, sistemas de preferências e sistema multilateral de comércio. Ao abrir a Assembléia Geral da ONU em 1991, Melo expressou a nova filosofia do Brasil: "O ideário liberal venceu... Essa é uma observação que faço da perspectiva de um país que optou por uma plataforma liberal”. Os dois presidentes retiraram do Estado o papel de "coordenação da economia” e reconheceram - segundo Luiz Carlos Bresser Pereira, um Ministro de Estado - "que essa coordenação cabe ao mercado". Indo além das exigências do chamado Consenso de Washington, a equipe de governo de Cardoso optou pela venda preferencial das empresas públicas às companhias estrangeiras. Obteve do Congresso uma lei de privatização para permitir que se fizesse pelos mecanismos de alienação. Os defensores mais arrojados dessa política foram os dois Ministros das Comunicações, Sérgio Motta e Luiz Carlos Mendonça de Barros, responsáveis pela maior transferência de patrimônio da periferia para o centro na era da globalização. À frente do Banco Nacional de Desenvolvimento Econômico e Social (BNDES), Francisco Gros deu prioridade a financiamentos de empresas estrangeiras sobre as nacionais nas privatizações.

Cardoso estava convencido de que dois benefícios resultariam da abertura tanto do mercado de consumo como dos sistemas produtivo e de serviços: libertar o Estado de encargos de dívidas contraídas pelas empresas públicas e melhorar a competitividade daqueles dois sistemas. É bem verdade que a resposta da economia brasileira foi positiva na medida em que o parque industrial modernizou-se e o desempenho elevou-se. Contudo, a privatização com alienação impediu a inserção internacional do país em condições de competitividade sistêmica, que demandava a expansão para fora de empresas de matriz nacional. Por efeito do Estado desenvolvimentista, o Brasil reunia as quatro condições para tanto - grandes empresas, capital, tecnologia e mercado - em nível muito superior às de pequenos Estados como Portugal e Espanha, que lograram uma inserção madura no mundo interdependente por haverem implementado políticas de padrão logístico.

Houve portanto, também no Brasil, adoção acrítica e ideológica do neoliberalismo, que erigiu o Estado normal latino-americano, reproduzindo no país, embora em menor escala, efeitos negativos que se generalizaram na região: aumento da transferência de renda ao exterior, inadimplência, repetidas corridas ao FMI, conversão do comércio exterior de instrumento estratégico de desenvolvimento em variável da estabilidade monetária, regressão do processo de desenvolvimento para dentro, aumento da desigualdade social, desemprego, desnacionalização e desindustrialização. E perda de poder de negociação de uma diplomacia atrofiada. As conseqüências do liberalismo sobre as economias emergentes foram resumidas por Rubens Ricupero, Secretário-Geral da X UNCTAD realizada em Bangkok em 
fevereiro de 2000: instabilidade estrutural, vulnerabilidade econômica, crescimento da pobreza, marginalização e insegurança. As políticas de vertente keynesiana introduzidas pelo governo de George W. Bush no segundo semestre de 2001 para relançar a economia norte-americana ameaçada por profunda recessão vinham lançar mais dúvidas sobre o acerto da abertura das economias periféricas.

Meio ambiente. A ação da diplomacia brasileira nesse terreno não permitiu que graves prejuízos ao país como aqueles advindos da gestão das relações econômicas externas se repetissem. Com efeito, era perceptível junto aos países avançados a intenção de utilizar o argumento ecológico como instrumento de pressão sobre os países em desenvolvimento para tolher-lhes riqueza e meios de ação. A estratégia brasileira envolveu iniciativas na esfera bilateral, multilateral regional e multilateral global. Obteve êxito em três sentidos: trouxe a chamada Cúpula da Terra para o Rio de Janeiro (junho de 1992), agregou na ocasião o tema do desenvolvimento ao debate sobre meio ambiente (Conferência das Nações Unidas sobre Meio Ambiente e Desenvolvimento) e substituiu o confronto norte-sul pela cooperação no trato da questão. A ECO 92 assistiu ao triunfo da tese brasileira do desenvolvimento sustentável acoplado ao meio ambiente. Dela resultaram a Agenda 21, um programa de cooperação multilateral, uma Convenção-Quadro sobre Mudança do Clima, que evoluiu para o Protocolo de Kyoto de 1997, e uma Convenção sobre Diversidade Biológica que resguarda direitos brasileiros sobre a Amazônia. O Brasil ratificou as duas últimas e envolveu-se oficialmente com a Agenda 21.

A competente ação da diplomacia brasileira reverteu na década de noventa as ameaças internacionais que pesavam sobre a Amazônia, com base em estereótipos tais como pulmão da humanidade, patrimônio da humanidade, reserva ecológica e outros, difundidos por Organizações Não-Governamentais e ordens religiosas que arrancavam pronunciamentos de chefes de Estado das grandes potências. Detentor da maior biodiversidade do planeta, o Brasil já incluíra no Tratado de Cooperação Amazônica de 1978 a necessidade da pesquisa. Como não a desenvolvia, a Convenção sobre Diversidade Biológica era violada pelo patenteamento no exterior de produtos amazônicos. Essa biopirataria provocou novas iniciativas governamentais, tendo em vista preservar a soberania e os direitos reconhecidos naquela convenção multilateral. Em 1995, o Congresso aprovou a Lei sobre Biossegurança, em 1996 a Lei de Patentes, em 1997 uma Lei de Cultivares e finalmente a Lei que regula o acesso aos recursos genéticos brasileiros. Todo esse ordenamento jurídico complementou-se com o Programa Piloto para Proteção das Florestas Tropicais do Brasil, envolvendo o Brasil, o G7 (grupo das sete maiores potências capitalistas), a União Européia e o Banco Mundial no mais vasto programa de cooperação ambiental do mundo.

O conceito de desenvolvimento sustentável, uma produção da engenharia diplomática brasileira, associado a esta diversificada estratégia de ação externa, 
afastou aparentemente a ameaça internacional e garantiu à nação os benefícios da riqueza biológica. Os críticos da legislação brasileira entendem, contudo, que os direitos sobre a biodiversidade e os recursos genéticos não foram protegidos ao ponto de evitar que a Amazônia venha também a ser alienada por padrões de conduta do Estado normal. Por sua vez, o Governo parece seguro sobre a arena internacional. Tanto é que enfrentou os Estados Unidos na Organização Mundial da Saúde em 2001, fazendo aprovar por 191 votos (inclusive o norte-americano) a quebra de patentes de indústrias farmacêuticas quando exigem graves condições da saúde pública, como a epidemia da síndrome da imunodeficiência adquirida (AIDS).

Direitos humanos. A política exterior do Brasil envolveu-se com os direitos humanos de modo distinto, em três fases: ao ensejo e logo após a Declaração Universal dos Direitos Humanos da ONU de 1948 foi assertiva na promoção desses direitos, adquirindo experiência no plano regional (Comissão Interamericana de Direitos Humanos) e global (Comissão de Direitos Humanos da ONU); a partir dos anos sessenta, em nome do constitucionalismo, mas em razão do regime autoritário, abandonou tal esforço, tomando posições defensivas e isolacionistas nos foros multilaterais; com o fim do ciclo autoritário, remediou-se e recuperou desde 1985 aquela ação assertiva original. A última fase foi preparada pelo professor da Universidade de Brasília, Antônio Augusto Cançado Trindade, renomado jurista internacional, Conselheiro Jurídico do Itamaraty e depois Presidente da Corte Interamericana de Direitos Humanos. O novo papel do Brasil na defesa e promoção universal dos direitos humanos desdobrou-se em duas dimensões, a primeira de ordem interna e a segunda externa.

Em 1992 consumou-se a adesão aos três tratados gerais de proteção, os dois da ONU e a Convenção da OEA. Conjugou-se essa iniciativa com a adesão às convenções internacionais específicas: contra a discriminação racial, da mulher, contra a tortura, sobre os direitos da criança, do refugiado. Em 1997, o Brasil reconheceu a jurisdição obrigatória da Corte Interamericana de Direitos Humanos. No mesmo ano, aprovou moderna lei sobre refugiados e entrou na rota do abrigo, particularmente para africanos. O Congresso exerceu a prerrogativa de adaptar sob todos os ângulos a lei brasileira, alinhada enfim aos avanços normativos internacionais. O Executivo criou a Secretaria de Estado de Direitos Humanos.

A conjugação dos esforços de juristas, diplomatas e legisladores produziu no Brasil uma percepção e um conceito original de direitos humanos que serviu de instrumento de ação positiva sobre o cenário internacional. Com efeito, o governo brasileiro entende que os direitos humanos - os liberais de primeira geração e os novos direitos econômicos, sociais, civis e culturais de segunda geração - são indivisíveis, como o ser humano, e sobrepõem-se aos particularismos religiosos ou culturais. A preocupação com os direitos humanos condiciona a ação externa do Estado e envolve a defesa da democracia e do desenvolvimento. Nesse último 
ponto, a criatividade política brasileira e sua expressão diplomática tiveram papel inovador na vinculação entre fruição de direitos humanos e condições de bemestar social alcançadas com o desenvolvimento econômico. Essa tese prevaleceu nas conclusões da Conferência Mundial de Direitos Humanos (Viena, 1993), onde a delegação brasileira presidiu o comitê plenário encarregado da redação da Declaração Final. Uma lógica ilustrada da globalização, nos termos de Celso Lafer, emerge dessa Conferência, provocando a responsabilidade dos governos em outro nível. Evidenciou-se desse modo o equívoco do Departamento de Estado americano e da União Européia que acusam em seus relatórios o Terceiro Mundo e a América Latina em particular de infringir os direitos humanos.

A diplomacia de Cardoso reforçou sua credibilidade com a nova face que exibiu. No transcurso dos cinqüenta anos da ONU, em 1995, cobrou sua função reguladora das relações internacionais mediante a criação de um corpus jurídico que não seja uma hipocrisia para as grandes potências. Cabe apenas à ONU sacrificar com legitimidade o princípio da soberania e da autodeterminação quando a defesa da paz e dos direitos humanos o requeiram. Cabe-lhe, por outro lado, reordenar o mundo para um ambiente de justiça e eqüidade social. No embalo da democracia e da promoção dos direitos humanos, a visão kantiana da paz e da justiça global contaminou portanto o discurso da diplomacia brasileira nos anos noventa, em contraste com o realismo político do comportamento das grandes potências ${ }^{2}$.

\section{O sacrifício da segurança nacional}

Embora não hesitasse em ceder as decisões na área das relações econômicas internacionais do país às autoridades econômicas, de vertente hayekiana, o Itamaraty apropriou-se nos anos noventa, com sua inspiração idealista de vertente grotiana e kantiana, da doutrina de segurança e da política de defesa, deprimindo o papel das Forças Armadas nessa área. Ao separar os dois campos estratégicos, o que nunca fizeram as grandes potências, distanciou-se do realismo e embarcou na utopia. Com efeito, segundo Robert Gilpin, a pax americana sempre forneceu a primeira razão dos investimentos americanos no exterior. Ao termo da Guerra Fria, fortes economicamente, os Estados Unidos e seus aliados autooutorgaram-se o direito de ingerência, exercido sob a auréola dos direitos humanos, porém sob a eficácia do realismo político que ausculta os próprios interesses.

A política exterior do Brasil desqualificou a força como meio de ação em favor da persuasão. O país abandonou a tendência iniciada nos anos 1970 em termos políticos com a transição da segurança coletiva para a nacional e em termos industriais com a produção de meios de defesa e dissuasão. Reforçou seu pacifismo, firmando os pactos internacionais de desarmamento. Ou seja, aplicou a mesma visão multilateralista no trato das questões econômico-comerciais e de segurança. 
O mundo após a Guerra Fria passou, todavia, do sistema bipolar para um sistema econômico multipolar e outro estratégico unipolar. O trato multilateralista convinha somente ao primeiro. Por isso, com o tempo, foi necessário temperar o idealismo kantiano da diplomacia brasileira, o que se fez de duas formas: elaborou-se em 1996 um documento político para nortear as decisões na área e buscou-se a união da América do Sul, tendo em vista precaver-se ante possível nocividade da hegemonia dos Estados Unidos.

As medidas de confiança mútua estabelecidas entre Brasil e Argentina desde os anos oitenta converteram-se em variável essencial da política brasileira de segurança. No país vizinho, as decisões também se deslocaram da área militar para a Chancelaria que afinou a princípio seu entendimento com a Chancelaria brasileira. Mais tarde, porém, a visão argentina revolveu antigos antagonismos, o que também contribuiu para a correção da política brasileira. Quando os programas nacionais dos dois países dominaram o ciclo completo da tecnologia nuclear, percebeu-se a necessidade de travar a corrida armamentista e de superar o dilema de ter ou não ter a bomba. Ambiente propício foi criado pelo Acordo Tripartite de 1979 que eliminou o contencioso acerca do aproveitamento dos rios. Em 1980, firmou-se o primeiro acordo de cooperação nuclear. Em 1985, já com os civis no poder, criou-se um grupo de trabalho conjunto, presidido pelos chanceleres, que deu origem a vários instrumentos. O processo de integração iniciado com a Ata de 1986 abrigou timidamente a cooperação nuclear. Mas o Tratado de Assunção que criou o Mercosul em 1991 animou a cooperação na área da segurança, particularmente a nuclear. Nesse mesmo ano, instituiu-se um sistema de fiscalização mútua, previu-se a entrada em vigor do Tratado de Tlatelolco e instituiu-se um sistema sui generis de salvaguardas com participação da Agência Internacional de Energia Atômica. Em 1994, entrou em vigência o Tratado de Tlatelolco para os principais países da região. Novos atos consolidaram a confiança mútua, até a criação em 2001 de uma agência bilateral para utilização pacífica da energia nuclear.

Na segunda metade dos anos noventa, esse ambiente propício à construção da zona de paz no Cone Sul da América foi perturbado pela obstrução argentina à pretensão brasileira de ocupar um posto como membro permanente no Conselho de Segurança e por sua insistência em integrar a OTAN com explícita intenção de secundar a ação dos Estados Unidos na América do Sul. Repugnava à diplomacia brasileira aquela subserviência, como também as propostas norte-americanas de criar instituições regionais de segurança e de confinar as Forças Armadas dos países da América do Sul no combate ao narcotráfico. Desconfiou, por isso, do Plano Colômbia de assistência militar norte-americano ao combate às drogas e empenhou-se vivamente para chegar à solução diplomática do conflito de fronteira entre Equador e Peru.

Por decisões de política exterior, o governo brasileiro movimentou-se na esfera da segurança global. Imbuído do idealismo kantiano, agiu com determinação 
nos foros de negociação no sentido de regular o sistema multilateral de segurança. Renunciou à construção da potência e ao exercício da força como instrumento da política ao aderir aos pactos de erradicação de armas químicas e biológicas de destruição massiva, ao Regime de Controle de Tecnologia de Mísseis e ao Tratado de Não-Proliferação Nuclear. Participou de inúmeras operações de paz sob a égide da ONU. Lançou em 1994 sua candidatura a membro permanente do Conselho de Segurança, mas depois abriu mão dessa pretensão, em favor de uma reforma que desse ao Conselho representatividade e legitimidade. Lamentou a perda gradativa de poder desse Conselho em favor de decisões unilaterais dos Estados Unidos, que a elas subordinavam a OTAN.

Com suas iniciativas pacifistas logrou, portanto, o governo brasileiro influir sobre o desarme do Cone Sul e a construção de uma zona de paz e cooperação na América do Sul. Animado com isso, desmontou o sistema nacional de segurança e renunciou ao realismo da ação na arena internacional. Malogrou quanto às expectativas de fixar um ordenamento regulatório multilateral para a segurança do mundo. Essas ambivalências entre realismo e idealismo permeiam o documento com que a Presidência da República fixou em 1996 a Política de Defesa Nacional. Esta resultou ambígua quanto à competência de sua execução por diplomatas, instituições civis e militares, quanto a seus meios de dissuasão e defesa e quanto aos fins a que pode servir. Contudo, nessa longa transição do Estado desenvolvimentista para outro paradigma, consumada a consolidação da democracia e percebidos os limites da utopia kantiana, a questão da segurança foi retomada como uma responsabilidade permanente e intrínseca da política exterior. A guerra contra o terrorismo desfechada pelos Estados Unidos após os atentados de 11 de setembro em Nova York e Washington revelou a imprudência, também no Brasil, de se relegar a segurança nacional a segundo plano ${ }^{3}$.

\section{O comércio exterior: a reversão da tendência histórica}

A abertura do mercado brasileiro nos anos noventa criou um desafio novo para o comércio exterior. A abertura destinava-se, pela lógica política, a forçar a modernização do sistema produtivo e a elevar sua competitividade externa. Visto que os fluxos do comércio não confirmavam tal fato, o governo passou a negociar em múltiplas frentes, visando com seus esforços alcançar do GATT-OMC um sistema multilateral com regras transparentes, fixas e justas e dos blocos regionais idênticos dispositivos. Incumbido dessas negociações, o Itamaraty não estava preparado para associar a sociedade e estimulá-la a fazer negócios externos, como ocorreu com a diplomacia empresarial no México e no Chile. Uma timidez sistêmica nacional, associada a fraquezas políticas e operacionais, reverteu a tendência histórica do comércio exterior brasileiro de gerar superávits. Nas mãos das 
autoridades econômicas, o comércio exterior deixou de ser instrumento estratégico de desenvolvimento e converteu-se em variável dependente da estabilidade monetária.

Certos equívocos dos economistas acompanham essa mudança a partir de 1990: o primeiro corresponde à convicção de que o protecionismo do mercado interno emperra o crescimento econômico; o segundo, à convicção de que o comércio exterior perdera a função de gerar saldos, podendo desempenhar a inusitada função de contenção da inflação; um terceiro dizia respeito à expectativa de que as potências avançadas cederiam aos diplomatas pela negociação aquele sistema multilateral, transitando do realismo que lhes permitia abusar ao idealismo kantiano brasileiro. Esses erros de cálculo tiveram alto custo.

Entre 1988 e 1993, o governo brasileiro reduziu a tarifa média de 52\% para $14 \%$ e eliminou todas as medidas não tarifárias. O Plano Real de estabilidade monetária de 1994 introduziu a sobrevalorização cambial. Em 1995, o comércio exterior reverteu a tendência para saldos negativos. O apoio público à liberalização arrefeceu, a tarifa média elevou-se desde 1996 e a moeda iniciou a desvalorização em 1999. A balança de comércio exterior registrou o superávit de 85,9 bilhões de dólares entre 1980-89. Entre 1990-94, o superávit atingiu 60,4 bilhões, mas entre 1995-2000, o déficit somou 24,3 bilhões. O saldo negativo aparece em 1995 e se repete nos seis primeiros anos do governo de Cardoso. Em termos absolutos, o comércio exterior avolumou-se nos noventa, passando de 52,1 bilhões de dólares em 1990 para 110,9 no ano de 2000.

O déficit do comércio contribuiu para a deterioração das contas externas. A conta de serviços, onde pesa sobretudo a renda do capital, registrou uma elevação do déficit anual médio de 13,6 bilhões de dólares durante a década de oitenta para 18,3 entre 1990-98. Além de transferir renda para o exterior através da remessa de enormes lucros realizados internamente, as novas empresas que operavam os serviços no Brasil em conseqüência de privatizações com alienação importavam equipamentos e componentes de suas matrizes; introduziram, pois, dupla variável de desequilíbrio das contas externas. A pauta das exportações brasileiras, por outro lado, tampouco registrou qualquer melhoria de qualidade com as inovações da abertura econômica. As séries históricas do Banco Central do Brasil indicam que ela se compunha, em 1989, de 71,1\% de produtos industrializados (54,3\% de manufaturados e $16,8 \%$ de semimanufaturados) e 27,1\% de primários; em 1997 , os industrializados somavam 70,9\% (com 54,9\% de manufaturados e 15,8\% de semimanufaturados) e os primários 27,1\%. Quando os aviões da EMBRAER tornaram-se o primeiro item das exportações, a partir de 1999, essas estatísticas sofreram modificações. Quanto às importações, a pauta modificou-se em razão da abertura, passando os bens de consumo de 5,7\% em 1980 para 18,2\% em 1997.

O comércio exterior enfrentou dificuldades conjunturais. No âmbito das negociações globais, em primeiro lugar. O governo brasileiro cedeu no GATT à 
pressão dos países avançados, reconhecendo o comércio dos serviços e da propriedade intelectual, aderiu aos TRIPs (Aspectos de Propriedade Intelectual Relacionados com o Comércio) em 1993 e aprovou a Lei de patentes em 1996. Continuou sendo acusado pelos Estados Unidos de desrespeitar este direito. Em razão de seu desemprego, os países centrais quiseram levar a cláusula social à OMC. Vendo nela um instrumento protecionista, o Brasil firmou posições em foros do Terceiro Mundo (Não-Alinhados, Grupo dos 77), aceitando discussões sobre cláusulas trabalhistas unicamente no âmbito da Organização Internacional do Trabalho (OIT) ou da Comissão de Direitos Humanos da ONU. Os países industrializados adotam, por outro lado, medidas ecoprotecionistas e fitossanitárias, contrariando normas multilaterais, o que não fazem os subservientes países pobres. Quando os litígios de comércio, particularmente os processos anti-dumping, eram levados aos mecanismos de solução de controvérsias da OMC, os julgamentos padeciam de vício político e davam ganho de causa aos ricos. Desde a criação da OMC, em 1995, até 2000, 90\% dos julgamentos foram favoráveis aos ricos. Em poucos deles, o Brasil levou vantagem, como no caso da exportação de gasolina para os Estados Unidos, de coco para as Filipinas, de café solúvel para a Europa e dos subsídios canadenses à indústria aeronáutica.

A essas dificuldades globais somavam-se as regionais. Os Estados Unidos mantinham seu arsenal de barreiras às importações brasileiras de manufaturados e primários, o que levou o Brasil a retardar as negociações para formação da Associação de Livre Comércio das Américas (ALCA), como adiante se verá. Com a disputa entre as empresas exportadoras de aviões, Bombardier e Embraer, o Canadá mostrou à diplomacia brasileira o duro jogo que significa lidar com contenciosos comerciais: escondeu seus subsídios, obteve sanções da OMC e, como demonstração de desprezo, castigou as exportações de carnes do Brasil alardeando pelo mundo uma contaminação de seu rebanho pelo mal da vaca louca, que não existia. A União Européia não abria mão dos subsídios agrícolas. Após a explosão do comércio zonal entre 1991 e 1998 - um oportuno desvio de comércio face aos obstáculos acima descritos - o Mercosul assistia à corrosão das regras aduaneiras e à multiplicação de contenciosos, em razão da incompatibilidade dos regimes de câmbio, fixo na Argentina e flexível no Brasil.

Esse quadro desfavorável forçou o governo brasileiro a evoluir da subserviência do Estado normal a uma política de comércio exterior mais realista e condizente com o comportamento do Estado logístico, patenteado pelos ricos. A convicção de que estes países chegariam ao sistema kantiano de comércio internacional, com regras e mecanismos transparentes e democráticos e com distribuição eqüitativa de benefícios entre países ricos e pobres, desvaneceu-se em 2000, ante o malogro da chamada rodada do milênio da OMC em Seattle ${ }^{4}$. 


\section{Fluxos de capital: a nova via da dependência}

A globalização financeira comportou duas exigências dos países avançados sobre as economias emergentes: o livre fluxo de capitais e a abertura dos sistemas financeiro, empresarial e dos mercados de valores a sua penetração. Quando as reformas do Estado satisfizeram tais exigências, dois também foram os efeitos que se generalizaram: o aumento dos fluxos, em boa medida de capitais especulativos, e as crises financeiras. Quando as crises financeiras abalavam essas economias (México em 1994-95, Ásia em 1997-98, Rússia em 1998 e Argentina em 2001), o G7 apenas de leve cogitou na possibilidade de introduzir controles ou salvaguardas para os efeitos predatórios dos capitais especulativos. O grupo dos ricos considerava pedagógicos tais prejuízos, exigindo reformas de segunda geração do FMI, mas eram com certeza as grandes transferências que provocavam em direção ao centro que o mantinha inflexível.

Nenhuma das grandes crises financeiras do período teve origem no Brasil. Contudo, este país sofreu a cada crise efeitos negativos sobre suas finanças. Por esta razão, a diplomacia de Fernando Henrique Cardoso cobrou dos dirigentes do G7 aquelas medidas de controle, requerendo para a arquitetura das finanças internacionais regras estáveis e justas, similares às do sistema multilateral de comércio de matiz kantiana, cuja regulamentação se esforçava por induzir junto à OMC. Não obstante, o G7 permanecia insensível e esta organização concluía apenas a regulamentação da abertura dos serviços financeiros e dos mercados de capitais que o governo brasileiro prontamente aplicava.

Dócil diante das reformas exigidas pelo centro, o governo brasileiro abriu todos os domínios de sua economia aos capitais internacionais: os serviços financeiros, a bolsa de valores, os bancos e as grandes empresas públicas no momento da privatização.

A abertura das comunicações no Brasil correspondeu ao maior negócio do mundo quanto à transferência de ativos de países emergentes para o centro do sistema capitalista. As pressões internacionais foram precoces e bem conduzidas. Durante a Rodada Uruguai, dizia-se que se tratava do setor com maior probabilidade de lucros nos países em desenvolvimento. Durante a reunião de Marrakesh de 1994 e no foro de Davos em 1997, os representantes norte-americanos exigiam a abertura incondicional como parte das regras da liberdade comercial. O projeto de lei de privatização da Telebras foi concebido por agências do exterior e embutiu as pressões externas. Com efeito, o Congresso Nacional contratou a União Internacional de Telecomunicações, uma firma de assessoria da ONU sob controle norte-americano, que por sua vez subcontratou a McKinsey \& Company. A Lei Geral de Telecomunicações de 1997 veio a público como queriam o governo dos Estados Unidos e os global players estrangeiros. Em consonância com esta filosofia política subserviente e destrutiva do patrimônio nacional, o Executivo autorizou no 
mesmo ano um aumento real de 350\% nos serviços básicos de telefonia com intuito de capitalizar as empresas privatizadas e desencadeou intensa campanha para impedir que a opinião pública percebesse o que se passava. Assim mesmo, a privatização da Telebras foi reprovada por $51 \%$ em pesquisa de opinião. Consumada a alienação das comunicações, a ANATEL, agência reguladora do setor, tornouse refém das multinacionais.

Os efeitos desse modelo de privatização com alienação sobre as estruturas brasileiras foram três: esterilização da inteligência nacional, dispensada de atuar no setor; nova via de transferência de renda mediante expatriação de bilhões de dólares anuais oriundos dos lucros fáceis do setor de serviços; dificuldades no comércio exterior, já que tais empresas se estabelecem para explorar o mercado local, importam seus equipamentos das matrizes e não se voltam para exportação a terceiros mercados. Esses efeitos negativos não se verificam em países avançados, porque estes equilibram sua abertura com internacionalização de suas economias. O comportamento logístico requeria, portanto, no momento da abertura, para compensar a alienação, a internacionalização da economia brasileira. Mas esta não contou com estímulo do governo, como ocorreu em Portugal, na Espanha e no México. Era incipiente em 2001 em termos de expansão de filiais, associações e faturamento no exterior.

Entre 1980-89, o movimento líquido de capitais estrangeiros no Brasil foi de 9,7 bilhões de dólares e de 91,1 bilhões entre 1990-98. Os investimentos diretos apresentaram um crescimento exponencial na década dos noventa, passando de 1,1 bilhões em 91 para 33,5 em 2000. Durante o período de maior fluxo, entre 1996 e 2000, 24,8\% eram capitais americanos, 17,4\% espanhóis, 9,3\% holandeses, 8,1\% franceses e 7,9\% portugueses. O desequilíbrio nas contas correntes do país advém das remessas de lucros, já que é baixo o índice de internacionalização da economia brasileira.

Durante o governo de Cardoso, entre 1995 e 2000, a dívida pública interna passou de 33\% para 53\% do PIB. Entre 1994 e 1999, a dívida externa elevou-se de 148 para 237 bilhões de dólares. Juros e amortizações da dívida externa consumiram 50 bilhões de dólares em 2000, ou seja, toda a exportação brasileira. O Brasil ostentava então nesse ponto um dos piores indicadores externos do mundo. Esse desequilíbrio induzia medidas malabaristas na taxa de juros para atrair constantes fluxos de capitais e provocou uma inflexão da política de comércio exterior, que evoluiu de sua função de estabilizar os preços para a nova função de prover recursos para os compromissos da dívida. O grave perfil das contas públicas, em sintonia com instruções vinculadas aos socorros concedidos pelo FMI desde 1990, retirava investimentos produtivos, provocando outras crises, como a escassez de energia elétrica, e bloqueava o crescimento econômico. O fluxo de capitais, marcado por movimentos especulativos, desapropriação dos ativos nacionais, remessa de lucros e serviços da dívida externa, aprofundou nos anos noventa a 
dependência estrutural do país, financeira e econômica. Correspondeu a uma ilusão de divisas cultivada sob o signo do neoliberalismo pelas autoridades do centro e da periferia. $\mathrm{O}$ Brasil transitou, pois, da década perdida à década perversa ${ }^{5}$.

\section{O bilateralismo em declínio nas relações internacionais do Brasil}

A política exterior assertiva do ciclo desenvolvimentista manipulava a relação bilateral e a parceria estratégica como uma linha de força da ação externa. O paradigma da globalização das relações internacionais e a disposição do governo brasileiro de influir sobre a regulamentação do sistema multilateral de comércio e sobre a arquitetura das finanças internacionais subtraíram energia ao bilateralismo. Entregue ao descaso brasileiro, o bilateralismo sofreu uma acomodação quanto ao papel dos grandes e pequenos determinada por causas exclusivamente exógenas. Os Estados Unidos mantiveram a exuberância de sua posição histórica como aliado especial do Brasil e a França retornou, enquanto a Alemanha se afastava e o Japão hibernava. Do lado dos pequenos, assistiu-se à chegada inesperada e dinâmica de Espanha e Portugal.

A política exterior dos Estados Unidos modificou-se em 1989, quando a contenção do comunismo deixou de ser o vetor. Desde então, outras tradições imprimiram coerência à ação externa, como a determinação de ditar as regras do sistema internacional em função de seus interesses e valores, particularmente a hegemonia econômica global. Desde 2001, embrenhou-se em campanha global de combate ao terrorismo. O país voltou-se para a liberalização comercial e financeira e para a racionalização da ação estratégica na presunção de existência de um inimigo externo, sucessivamente o Irã, o Iraque, a Iugoslávia, o Afeganistão. Como o Brasil era subserviente, mas não tanto, foi possível administrar as relações bilaterais em clima de cordialidade desconfiada.

Durante os dois mandatos do democrata Bill Clinton, a partir de 1993, manteve-se clima de entendimento, mesmo porque tinha ele com Cardoso uma relação pessoal afetiva. A diplomacia brasileira não perdia oportunidade de colocar em evidência a histórica parceria bilateral, alicerçada na comunhão de visões políticas da época do Barão do Rio Branco e na estratégia de cooperação bilateral com benefícios recíprocos posta em marcha desde Vargas. A ascensão do republicano George W. Bush em 2001 colocou Cardoso com um pé atrás e motivou o Senado brasileiro a estabelecer diretrizes para a negociação da ALCA.

Os interesses em jogo nas relações bilaterais eram os do investimento norte-americano no Brasil, que se manteve firme no período (44,6\% do total entre 1990-94, 26,1\% entre 95-97), e o comércio bilateral, que cresceu $100 \%$ entre 1990 98, porém com déficits para o Brasil, da ordem de 13,5 bilhões de dólares entre 1995-99. A percepção de que o governo norte-americano requeria o multilateralismo e a liberalização do comércio, porém mantinha medidas de proteção das mais 
arcaicas contra produtos brasileiros, influiu sobre a política brasileira. Desconfiada, esta passou a obstruir o projeto norte-americano de hegemonia continental a ser implantado por meio das regras da ALCA.

Com efeito, enquanto a média tarifária dos 15 principais produtos brasileiros que entravam no mercado norte-americano ao termo dos anos noventa era de 45,6\%, a média para os produtos americanos no Brasil situava-se em 14,3\%. O arsenal protecionista dos Estados Unidos castigava as importações provenientes do Brasil. Compreendia as seguintes medidas: a) o suco de laranja era sobretaxado, atingindo o pique de 492 dólares por tonelada em 1995, além de 2,5\% remanescentes de um processo anti-dumping de 1986; b) os calçados enfrentavam tarifas médias de $8 \%$ a $10 \%$, aplicadas também contra outros fornecedores; c) as carnes bovinas ou de aves cruas ou congeladas eram proibidas por medidas fitossanitárias, as enlatadas sofriam restrições e as exportações subsidiadas de aves dos Estados Unidos prejudicavam o Brasil em terceiros mercados; d) as restrições fitossanitárias eliminavam na prática frutas e legumes brasileiros do mercado norte-americano; e) quanto aos produtos siderúrgicos, as restrições voluntárias impostas nos anos setenta e oitenta foram substituídas por processos anti-dumping e anti-subsídios nos noventa, como se os capitais estatais aportados à siderurgia antes da privatização produzissem efeitos perpétuos; f) a partir de 1985, o etanol brasileiro foi barrado por pressão dos produtores locais, tornando-se $72 \%$ mais caro em razão do imposto de importação; g) desde 1982, o governo concede subsídios ao produtor interno e controla a importação do açúcar por um sistema de quota.

Esses entraves, agravados pela concorrência e pelo grau de exigências do mercado norte-americano, condicionam o comércio de exportação do Brasil, direcionando-o para outros mercados, particularmente dos países vizinhos. As reclamações brasileiras junto ao GATT-OMC foram vãs, em geral, porém a criação da ALCA, condicionada à solução prévia dos contenciosos comerciais, pôde, sim, ser retardada. Embora o mercado norte-americano permaneça o alvo principal das exportações, são os investimentos diretos no Brasil o elemento de cálculo determinante das relações bilaterais.

As relações entre o Brasil e seu segundo parceiro histórico, a Alemanha, evidenciaram enorme perda de substância desde 1990. O investimento alemão no Brasil que ocupava a segunda posição praticamente desaparece ( 2,9\% entre 199094, 1,9\% entre 1995-97). O comércio bilateral, também o segundo em volume, perde para a Argentina, aliás registra um enorme déficit para o Brasil, da ordem de 12 bilhões de dólares entre 1993-98. A Alemanha abandonou a competição histórica com os Estados Unidos no sistema produtivo brasileiro, não participou das privatizações, e o Brasil não encontrou o caminho do mercado alemão. Quando se aprofundou a integração lá e aqui, as lideranças dos dois países sacrificaram a parceria estratégica em favor de ações nas adjacências. 
O Japão fornece outro exemplo de declínio do bilateralismo. Desde 1980, a parceria com o Brasil arrefeceu. Novas técnicas de produção diminuíram a demanda de matérias-primas e a valorização do iene orientou os investimentos para países asiáticos de mão-de-obra barata.

Por sua vez, a França veio atrás do espaço deixado pelos parceiros de outrora. Relações históricas inertes foram substituídas por recente dinamismo. Concertou-se a imagem desfavorável do Brasil na França, firmou-se novo AcordoQuadro de Cooperação, planejaram-se ações de médio prazo e estabeleceu-se inédita cooperação fronteiriça na Guiana Francesa. Receoso ante o processo de formação da ALCA e vendo no Brasil a porta de acesso à América Latina, o governo francês propôs a cúpula entre chefes de Estado e de governo das duas regiões e pressionou Mercosul e UE à negociação de acordo bilateral de comércio. Os investimentos franceses no Brasil que eram concentrados nos velhos estoques de Rhône-Poulenc, Saint Gobain, Sudameris e Crédit Lyonnais trouxeram novos grupos como Carrefour, Electricité de France, Michelin, Alcatel Alstom, Thomson, Aérospatiale, Air Liquide, Renault e Peugeot. O comércio bilateral não acompanhou esta expansão dos investimentos, permaneceu abaixo dos 3\% do comércio total do Brasil entre 1990-99 e teve no protecionismo agrícola francês o pomo de discórdia.

Quando ocorreu a reconversão da Rússia ao capitalismo, as relações com o Brasil despertaram grande interesse, por serem dois Estados-pivô, com potenciais tecnológicos e comerciais de países continentais modernos. A diplomacia foi rápida em firmar acordos de cooperação nos mais diversos domínios, particularmente o espacial em que ambos são detentores de todo o ciclo. Os acordos refletem uma nova filosofia ao utilizarem explicitamente o termo parceria estratégica a ser implementada por meio de múltiplas ações previstas. O comércio não refletiu esse dinamismo diplomático. Aliás, o alto grau de prioridade conferido às relações bilaterais por intenções fundadas em adequada avaliação de potencialidades não havia aberto, até 2001, vias substantivas de realizações concretas.

A China, porém, teve maior senso prático. As relações entre China e Brasil também foram qualificadas de parceria estratégica nos anos noventa, denotando a alta prioridade que se lhes conferia. À diferença da Rússia, a China contribuiu para colocar o Brasil na era espacial. A cooperação tecnológica resultou no lançamento conjunto de satélites de sensoriamento e no domínio da construção de veículos lançadores. Privilegiou, portanto, a questão ambiental. As grandes possibilidades de cooperação entre os dois maiores países em desenvolvimento do mundo foram percebidas pelos dirigentes também no setor de energia, da política internacional, da indústria pesada e dos serviços de engenharia.

O mercado dos grandes países não contou com estratégia eficiente de promoção comercial por parte do governo brasileiro desde 1990. Absorto em imaginar benefícios da abertura unilateral do mercado brasileiro, concentrou esforços inúteis na regulamentação do sistema multilateral de comércio por um lado e, por 
outro, do Mercosul, com algum proveito. A chegada dos pequenos países em consequiência da abertura do sistema produtivo e de serviços, se resultou em nova fonte de investimentos, tampouco trouxe solução para o déficit do comércio exterior.

As relações entre Espanha e Brasil põem terno nos anos noventa ao distanciamento tradicional. Politicamente, a Espanha assimilou o mundo luso e se apresentou como nexo entre Europa e América Latina. Percebeu cada país a importância do outro nos processos regionais de integração. No Brasil o governo e na Espanha os empresários assumiram o papel protagônico dessa nova fase das relações bilaterais. Aproveitando com esperteza as oportunidades abertas pela privatização, os capitais espanhóis fizeram a festa no Brasil, situando-se em primeiro lugar no ano 2000, com investimentos de 9,6 bilhões de dólares. Os mais importantes grupos de recém-chegados penetraram os serviços de rentabilidade elevada e imediata: Sol Meliá, na área hoteleira, Telefônica (com lucro de 379,9 milhões de dólares apenas no primeiro trimestre de 2001), Endesa e Iberdrola que operam na área de eletricidade, Santander na área bancária e Pisa na área editorial.

Com seu porte reduzido, Portugal seguiu os passos de Espanha, investindo mais de 5 bilhões de dólares no Brasil nos anos noventa. Apesar de vínculos afetivos, estimulados sobretudo durante os governos de Itamar Franco e Mário Soares, a Comunidade de Países de Língua Portuguesa (CPLP) de pouca valia foi para o reforço da estratégia bilateral. Aliás, nem o governo brasileiro nem seus agentes econômicos privados compensaram a penetração ibérica no Brasil com iniciativas de internacionalização da economia brasileira e de penetração no mercado europeu. Enquanto Portugal e Espanha ostentavam comportamento de Estado logístico e promoviam a inserção madura de suas economias, permanecia o Brasil refugiado na subserviência do Estado normal, inerte e regressivo.

As reformas neoliberais que se espalharam pela África nos anos noventa aproximaram o continente da América Latina em termos de mau desempenho interno e de inserção dependente. Pouco proveito tiraram nesse contexto as empresas brasileiras que se haviam instalado na África sub-saárica, como a Petrobras e a Odebrecht. As exportações brasileiras entraram em declínio a partir de 1986 e só recobraram alento no ano de 1999. As expectativas da África do Sul após o fim do apartheid, bem como da Nigéria e de Angola, quanto à cooperação do Brasil para o desenvolvimento, frustraram-se ${ }^{6}$.

\section{O Brasil e a formação dos blocos}

\section{O Mercosul nas relações internacionais do Brasil}

Os acordos Sarney-Alfonsín dos anos oitenta correspondiam a um projeto neoestruturalista de integração, estratégico do ponto de vista econômico e político. Já o Tratado de Assunção de 1991 que criou o Mercosul imbuiu-se da filosofia 
política do Estado normal que impregnou os governos de Fernando Collor de Melo e Carlos Saúl Menem. A integração industrial e o desenvolvimento cederam em favor da desgravação linear do intercâmbio e do regionalismo aberto. Desde então, interna e externamente, nenhuma estratégia foi concebida para além do comércio. A entrada em vigor da Tarifa Externa Comum em 1995, se criou o segundo mercado comum do mundo, aprofundou as contradições do processo, agravadas pela desvalorização do real em 1999 e pela crise de insolvência da Argentina em 2001. Nesse ano, recuava-se em sua implantação e estabeleciam-se mecanismos que comprometiam a própria zona de livre comércio. Apesar disso, o Mercosul recolheu a adesão como membros associados de Chile e Bolívia e o pedido da Venezuela. Encetou negociações bilaterais sob a fórmula quatro mais um com parceiros externos como os Estados Unidos em 1991 e coletivas como os acordos com a União Européia e a Comunidade Andina. Quando completou dez anos, em 2001, suscitou avaliações contraditórias, que se podem resumir em seis êxitos e seis fragilidades.

Os resultados positivos do processo de integração do Cone Sul foram concretos e de profundo alcance histórico para a vida dos povos:

1) Impressionante empatia entre a inteligência brasileira e argentina embalou o movimento desde o berço e aproximou o sentimento nacional. Essa dimensão humanista do processo, a dar inveja a franceses e alemães, expressou-se na multiplicação de encontros promovidos por lideranças sociais - acadêmicos, diplomatas, empresários, sindicalistas, artistas, autoridades - de que resultou grande número de livros e artigos acerca de afinidades e diferenças, gostos, virtudes e fraquezas, por sobre o acompanhamento que se fazia do processo. Considerando-se a promoção do conhecimento, a demolição de preconceitos e tabus e a adaptação da imagem do outro, o balanço foi positivo em termos de convivência que se aceitou como inevitável.

2) As novas condições psicossociais conduziram naturalmente à criação da zona de paz no Cone Sul, com impacto positivo sobre a América do Sul. Após haverem cultivado a rivalidade histórica durante séculos e atingido a capacitação plena para produção de armas nucleares, Brasil e Argentina abandonaram a corrida armamentista, jogaram a bomba no lixo e implantaram um sistema único no mundo de confiança mútua por meio de instrumentos jurídicos e operacionais. A cláusula democrática contribuiu para este fim, como também para dissuadir assaltos ao poder tão freqüentes na história regional.

3) O comércio intrazonal elevou-se de 4,1 bilhões de dólares em 1990 para 20,5 em 1997, 18,2 em 2000. No período, as exportações do bloco cresceram 50\% e as importações $180 \%$. O regionalismo aberto provocou, portanto, um desvio de comércio, extremamente oportuno para economias incapazes de elevar-se à competitividade sistêmica global. O Paraguai converteu-se em oitavo comprador do Brasil, à frente da Grã-Bretanha. 
4) O Mercosul tornou-se sujeito de direito internacional pelo protocolo de Ouro Preto de 1994, podendo negociar sobre a arena internacional. Durante a XX Cúpula (Assunção 2001), instituiu-se um mecanismo coletivo de negociação. Por outro lado, o arcabouço jurídico do bloco exibe 500 páginas de documentos normativos relativos às seguintes esferas: antecedentes, integração, consulta e solução de controvérsias, certificação de origem, comércio e aduana, regimentos, relacionamento externo, justiça, educação e cultura, regulamentos técnicos.

5) Sendo o segundo mercado comum do mundo e havendo queimado etapas em sua construção, o Mercosul produziu externamente uma imagem positiva acima da própria realidade e fortaleceu seu poder de barganha como bloco e o de seus membros isoladamente.

6) O processo alavancou a idéia de América do Sul, que tomou forma na proposta de criação de uma zona de livre comércio, na Cúpula de Brasília de 2000, nas negociações entre Mercosul e Comunidade Andina e, enfim, no controle, sob liderança brasileira, do ritmo e da natureza do processo de criação da ALCA, como se observou na Cúpula hemisférica de Quebec de 2001 sobre o tema.

O ceticismo das avaliações ao cabo de dez anos de Mercosul evidenciavam as fraquezas do processo de integração, também em número de seis:

1) Distintas visões de mundo e políticas exteriores não convergentes minaram a negociação coletiva e as relações entre os membros. Concepções de globalização benéfica ou assimétrica, de desenvolvimento autônomo ou dependente, atitudes de subserviência ou divergência diante dos Estados Unidos e idéias sobre segurança global colocaram em linha de choque as diplomacias de Brasil e Argentina.

2) A recusa de sacrificar a soberania nas políticas públicas internas e externas impediu a coordenação de políticas macroeconômicas e a negociação coletiva em foros como OMC, FMI, BM, UNCTAD e OCDE.

3) Havendo sacrificado o propósito de robustecer o núcleo econômico nacional, o processo de integração elegeu o comércio exterior como núcleo forte. Os membros do grupo adotaram, contudo, medidas unilaterais, desmoralizando o mecanismo da tarifa externa comum que haviam implantado.

4) O Mercosul engendrou um processo de integração assimétrico que não criou mecanismos de superação de desigualdades entre os membros e, no interior destes, entre zonas hegemônicas e periféricas, como sucedeu com o processo europeu. Frustrou, portanto, a expectativa de elevar o nível social do conjunto.

5) A incompatibilidade das políticas cambiais entre os dois grandes parceiros do bloco - a Argentina com a paridade entre o peso e o dólar e o Brasil com seu câmbio flexível - provocou desconfianças e inúmeros contenciosos comerciais. 
6) Ao elevar-se da condição de zona de livre comércio para a de união aduaneira sem instituições comunitárias, o Mercosul criou a contradição de essência. Enfraqueceu a negociação internacional, feita pelos Estados, e manteve o processo negociador interno extremamente complexo, visto ser necessário acionar a cada decisão quatro processos decisórios autônomos ${ }^{7}$.

\section{A integração da América do Sul e a ALCA}

As relações entre o Brasil e seus vizinhos responderam a apelos históricos contraditórios: isolamento, boa vizinhança, liderança. Imagens e percepções dos dois lados condicionaram a estratégia regional. Também as afinidades e diferenças. A Argentina, rival diminuída, disputou com o Brasil a influência sobre Uruguai, Paraguai e Bolívia. O Brasil contou historicamente com o Chile e, desde o Tratado de Cooperação Amazônica de 1978, com os países amazônicos. A confiança mútua engendrada nas relações com a Argentina recuperou a idéia de Rio Branco de liderar a América do Sul em sintonia com esse vizinho maior, se possível.

Desde o início da década de 1990, o Brasil traçou uma estratégia regional que permaneceria invariável: reforço do Mercosul com convergência política entre Brasil e Argentina e organização do espaço sul-americano com autonomia perante os Estados Unidos.

Em 1993, com apoio do Mercosul, da Colômbia e da Venezuela, o presidente brasileiro Itamar Franco lançou a iniciativa de formação em dez anos da Área de Livre Comércio Sul-Americana (ALCSA). Era a idéia de unidade da América do Sul em marcha, e não mais da América Latina, visto haver-se o México orientado para o norte. Desde então, o Brasil contrapôs essa proposta de chegar à ALCA pelo Mercosul à proposta alternativa norte-americana de alcançá-la desde o NAFTA (Associação de Livre Comércio da América do Norte). A construção hemisférica de blocos já contava, aliás, com as vertentes continental (OEA) e latina (SELA). O Brasil foi o único país americano a dizer não aos moldes com que George Bush propôs em 1991 a Iniciativa para as Américas, reafirmada pela Cúpula dos 34 países americanos em Miami em 1994, na de Santiago em 1998 e de Quebec em 2001. Desse modo, os ministros dos 34 países que se reúnem anualmente para negociar o processo de formação da ALCA não chegam a conclusões convergentes para provocar decisões concretas durante as cúpulas.

A integração da América do Sul foi alçada ao nível de condição prévia para a integração hemisférica pela diplomacia brasileira. Os argumentos a favor dessa estratégia eram três: a expansão dos interesses comerciais e empresariais brasileiros sobre a região, a conseqüente elevação de seu desempenho e competitividade e a percepção de que a proposta norte-americana destinava-se a alijar a hegemonia brasileira em benefício próprio. Em 2001, deixou-se claro que o comércio bilateral erigia-se como outra condição para negociar a ALCA, exigindo- 
se a remoção prévia do arsenal protecionista norte-americano, acima descrito. A diplomacia brasileira foi muito ativa para evitar a defecção da Argentina e do Chile, cujos governos inclinavam-se para o NAFTAe estavam propensos a antecipar a implantação da ALCA de 2005 para 2003. Cardoso relançou a idéia da ALCSA a construir por acordos de comércio entre Mercosul e Comunidade Andina, com adesão do Chile. Convocou para Brasília os doze presidentes e realizou em 2000 a primeira Cúpula da América do Sul, com o objetivo de aprofundar os vínculos políticos e de acelerar a criação da zona de livre comércio pela fusão do Mercosul com a Comunidade Andina e a adesão plena do Chile ao primeiro. Por ocasião da mediação bem sucedida do conflito fronteiriço entre Peru e Equador, Cardoso afirmou em 1998 que a América do Sul resolve seus problemas, mesmo os militares, por si e sem intervenção externa de qualquer natureza. Influiu depois na contenção da ação militar norte-americana que se presumia intensa por meio do Plano Colômbia de combate às drogas.

O modelo de integração do Mercosul como união aduaneira imperfeita favoreceu, portanto, o Brasil, em termos de ganhos e perdas. O Brasil conservou sua autonomia decisória e soube usar o bloco em outros quadrantes. Não avançou quanto desejava na construção do bloco sul-americano em seu benefício, porém retardou o prejudicial bloco hemisférico. Contou nos anos noventa com a convergência quase perfeita da visão regional e mundial por parte da diplomacia venezuelana, que aliás desprezou com evidente descaso. Entregues aos parâmetros de conduta do Estado normal, os outros governos da América do Sul estavam inclinados pela lógica à subserviência diante dos Estados Unidos e à ilusão de que a abertura ilimitada de suas economias, com alienação destrutiva, trar-lhes-ia a desejada inserção competitiva no mundo da globalização. Esse obstáculo aos desígnios de liderança brasileira no ordenamento regional foi paradoxalmente suspenso pela recusa do Congresso norte-americano em conceder autorização ao Executivo para negociar livremente a ALCA. Ademais, o movimento de introspecção da economia norte-americana, em razão de recessão prevista após os atentados terroristas de setembro de 2001, aliviou o temor de uma imposição da ALCA sob pressão ${ }^{8}$.

\section{As relações do Brasil com outros blocos}

Ao mesmo tempo em que negociava a ALCA, o governo brasileiro utilizava o Mercosul para negociações coletivas com a UE. Um Acordo-Quadro de Cooperação Interinstitucional foi firmado em 1992 e outro Inter-Regional de Cooperação em 1995. O primeiro tinha caráter pedagógico, de influência política dos europeus sobre a integração do Cone Sul. O segundo visava a zona de livre comércio. Para tanto, criou diversos mecanismos de negociações, encetadas em quinze esferas de ação. Entre 1992 e 1997, o comércio entre os blocos cresceu 
266\% e os investimentos diretos da UE no Mercosul 700\%, atingindo 7,9 bilhões de dólares. Durante a Primeira Cúpula Euro-Latino-Americana de junho de 1999, a Cúpula Mercosul-União Européia decidiu abrir as negociações para construção de uma zona de livre comércio que também envolvesse fórmulas de união política. Três rodadas de negociação ocorreram até 2000, com magnitude superior às negociações que se levavam a efeito para a instalação da ALCA. A zona de livre comércio entre Mercosul e UE apresentava-se, portanto, como alternativa viável à zona hemisférica sob hegemonia dos Estados Unidos, e com a qualidade de contemplar a dimensão da cidadania, da democracia e da convivência política. Cardoso condicionou sua criação, prevista para 2005, à eliminação dos subsídios o do protecionismo agrícola em vigor na Política Agrícola Comum. O ativo estratégico erguido na Europa fortalecia a liderança do Brasil na América do Sul e sua disposição de não sacrificar interesses essenciais nas negociações com os Estados Unidos, como estava disposto a fazê-lo seu sócio principal, a Argentina.

Do lado da África, a diplomacia coletiva do Mercosul concluiu em 2000 um acordo com a África do Sul para formação da zona de livre comércio. A Zona de Paz e Cooperação do Atlântico Sul, criada em 1986 por resolução da ONU, constatou em sua terceira reunião, em 1994, que sua ação se diluía nos órgãos regionais, particularmente nas negociações entre Mercosul e Comunidade para o Desenvolvimento da África Austral, entre o Mercosul e a Comissão Econômica dos Estados da África Ocidental ou ainda entre o Brasil e a Comunidade de Países de Língua Portuguesa. Esta última, instituída em 1996 como foro de concertação política, cooperação econômica e promoção da língua portuguesa foi tímida diante das soluções que poderia alcançar para a guerra civil na Angola e nenhum poder de pressão internacional exerceu diante da tragédia do Timor Leste.

Em 1998 criou-se como mecanismo informal o Fórum de Cooperação América Latina-Ásia do Leste com a finalidade de fomentar o diálogo político e a cooperação. Reunia 15 países da América Latina, inclusive o Brasil, e 15 outros da Ásia do leste e da Oceania, incluindo China, Japão e Austrália. A primeira reunião de chanceleres ocorreu em 2001. O CARICOM (Caribbean Community), bloco de 15 países efetivado em 1973 não atraiu a atenção bilateral do Brasil ou coletiva do Mercosul $^{9}$.

\section{Conclusões}

Durante seus dois mandatos, Fernando Henrique Cardoso obteve êxito no propósito de manter a estabilidade econômica interna e elevar a produtividade. Ao acoplar o setor externo e esses objetivos internos, corrompeu a funcionalidade da política exterior. Seu governo confundiu abertura com estratégia ${ }^{10}$ e sacrificou a política exterior, que deixou de servir ao desenvolvimento e à superação de 
dependências estruturais. Em outros termos, não formulou uma estratégia de inserção internacional, para além da simples abertura.

O balanço das relações internacionais do Brasil durante a era Cardoso tornou-se, destarte, medíocre, senão desastroso, considerando a realização de interesses nacionais.

Cardoso falhou em três pontos: expôs as finanças à especulação, converteu a política de comércio exterior em variável da estabilidade de preços e alienou boa parte do núcleo central robusto da economia, mediante o mecanismo da privatização com transferência de ativos ao exterior. Aprofundou, desse modo, a vulnerabilidade externa, tornando-a uma das mais graves entre os países emergentes.

Esses erros conduziram a resultados negativos da ação externa: em primeiro lugar, à tradicional via dos serviços da dívida, Cardoso acrescentou duas novas vias de transferência de renda ao exterior, a dos dividendos e a dos altos juros reais; em razão disso, elevou o passivo externo do país a um patamar de alto risco segundo a boa regra econômica; enfim, um comércio exterior quase estagnado deixou de servir ao desenvolvimento e ao alívio do balanço de pagamentos. Nenhuma criatividade revelou o Presidente em acionar mecanismos de equilíbrio dessas condutas - que por isso são erros de cálculo político - como fazem os países maduros.

O governo de Cardoso viveu de três ilusões: acreditou no ordenamento multilateral que haveria de resultar de negociações, as quais produziriam regras justas, fixas, transparentes e respeitadas por todos para o comércio internacional, as finanças, o meio ambiente e a segurança; a ilusão de divisas, como se os capitais externos que entraram no país em razão de uma abertura indiscriminada não agravassem o desequilíbrio do balanço de pagamentos; enfim, investiu no prestígio do presidente intelectual, como se tal áurea fosse suficiente para dar cobertura aos interesses brasileiros.

O movimento da diplomacia e o desempenho das autoridades econômicas submeteram-se a tais ilusões, que alimentavam por intensa atividade, a primeira, e por decisões coerentes, as segundas.

A dispersão da política exterior, que não traçou rumo firme, a não ser os parâmetros do que chamamos de Estado normal - subserviente, destrutivo e regressivo - foi a marca do governo de Cardoso. Lidou com a integração do Cone Sul e da América do Sul, com negociações simultâneas do lado da ALCA e da União Européia, privilegiou o multilateralismo sem abandonar o bilateralismo tradicional. A essas diversas frentes de ação faltou o cimento de uma estratégia de inserção madura no mundo da interdependência global, a dar significado a cada dimensão do envolvimento externo. Duas linhas de força da ação externa erigiram como prioridades a contribuição ao ordenamento multilateral, o lado idealista, e o interesse pela integração no Cone Sul, o lado realista. Ambas colheram frutos medíocres tendo em vista a realização de interesses. 
Apesar dessa dispersão, talvez em razão dela, o Brasil de Cardoso manteve controle circunstancial de males que se abateram com conseqüências mais graves sobre países vizinhos. Avançou menos pelo caminho do paradigma latino-americano do Estado normal. Manteve algo da conduta do Estado desenvolvimentista, o paradigma histórico que agonizou, mas não morreu. Enfim, pôs em marcha uma tímida experiência de Estado logístico. ${ }^{11}$

Em suma, o Brasil de Cardoso deixou-se seduzir pela miragem da mudança, perseguida com fúria ideológica, tomou o país em um nível de desenvolvimento histórico que reunia todos os elementos para uma inserção moderna no mundo da globalização e manipulou o setor externo por modo a provocar um salto para trás, a considerar o lastro de potencial acumulado a duras penas por esforços do Estado e da nação, durante os sessenta anos anteriores.

\section{Notas}

1 Os textos publicados por órgãos do Ministério das Relações Exteriores, como a Fundação Alexandre de Gusmão (FUNAG) e o Instituto de Pesquisa de Relações Internacionais (IPRI), ou disponibilizados pelos sites http://www.relnet.com.br e http://www.mre.gov.br foram utilizados em todo o capítulo tanto para a fundamentação conceitual da política exterior brasileira quanto para a coleta de informações empíricas sobre sua implementação. Dentre as publicações da Chancelaria brasileira, referimos a seguir as mais importantes: Reflexões sobre a política externa brasileira, 1993; A inserção internacional do Brasil: a gestão do Ministro Celso Lafer no Itamaraty, 1993; A política externa do Governo Itamar Franco, 1994; Política Externa. Democracia. Desenvolvimento. Gestão do Ministro Celso Amorim no Itamaraty 1995; Política externa em tempos de mudança: a gestão do Ministro Fernando Henrique Cardoso no Itamaraty, 1994; Presidência da República, Fernando Henrique Cardoso. Política Externa: pronunciamentos, 1995; Política externa em tempo real; a gestão do Embaixador Sebastião do Rego Barros no Itamaraty, 1999; A palavra do Brasil nas Nações Unidas, 1946-1995, 1995. Luiz Felipe LAMPREIA, Diplomacia brasileira: palavras, contextos e razões. Rio de Janeiro: Lacerda Ed., 1999. Da Resenha de política exterior do Brasil, outrora uma publicação periódica regular, foram publicados alguns números sem regularidade, porém os demais estão disponibilizados no relnet.

Carta Internacional, o boletim da Universidade de São Paulo, acompanha em seus artigos o movimento da diplomacia brasileira e as questões internacionais. Os principais autores utilizados foram os seguintes: Luis RUBIO, nº 73, 1999; Amado Luiz CERVO, 71, 1999; Luís Augusto SOUTO MAIOR, 71, 1999; Ana Flávia BARROS-PLATIAU e Marcelo Dias Varela, 96, 2001; Denilde Oliveira HOLZHACKER, 58, 1997; Roberto Teixeira da COSTA, 59, 1998; Amâncio J. OLIVEIRA, 85, 2000; José Augusto Guilhon ALBUQUERQUE, 59, 1998; Janina ONUKI, 83, 2000; José GENUÍNO, 71, 1999.

A Revista Brasileira de Política Internacional, com publicação regular, descreve as relações internacionais do Brasil e aprofunda sua análise. Os principais autores utilizados foram os seguintes: Fernando Henrique CARDOSO, A política externa do Brasil no início de um novo século, 44 (1), p. 5-12, 2001); J. A. Lindgren ALVES, A Cúpula Mundial sobre o Desenvolvimento Social e os paradoxos de Copenhague, 40 (1), p. 142-166, 1997; Luiz Felipe de Seixas CORRÊA, O Brasil e o mundo no limiar do novo século: diplomacia e desenvolvimento, 42 (1), p. 5-29, 1999; Luiz Felipe LAMPREIA, A política externa do governo FHC: continuidade e renovação, 
42 (2), p. 5-17, 1998; Lúcio ALCÂNTARA, Os parlamentos e as relações internacionais, 44 (1), p. 13-21, 2001.

Ver Celso LAFER, Brazilian International Identity and Foreign Policy: Past, Presente, and Future. Daedalus, Spring 2000, p. 226 e o número temático da revista Parcerias Estratégicas, 7, 1999. As referências dos livros utilizados neste parágrafo constam na bibliografia ao final da obra: Lafer (1999); Saraiva (2001); Guimarães (1999); Danese (1999); Bernal-Meza (2000); Cervo (2001). Ver ainda Fernando Henrique CARDOSO e Mário SOARES, O mundo em português. Um diálogo. São Paulo: Paz e Terra, 1998; Ricardo BIELSCHOWSKY (org.), Cinqüenta anos de pensamento na CEPAL, Record, 2000.

Livros: Alves (1994); Trindade (1998); Lafer (1999). Ver João P. M. PEIXOTO (org.), Reforma e modernização do Estado; aspectos da experiência brasileira recente, Sobral: UVA, 2000; Luiz Toledo MACHADO, O preço do futuro: um modelo de reconstrução nacional. Petrópolis: Vozes, 2000. Artigos dos seguintes autores em Carta Internacional: Patrícia Leite MIRANDA, 97, 2001; Michel Henry BOUCHET, 88, 2000; Ricardo U. SENNES, 86, 2000; Marília COUTINHO, 91, 2000; Eduardo VIOLA, 97, 2001; Fernando Henrique CARDOSO, 94-95, 2001; Rita CASARO, 96, 2001; Paulo Roberto ALMEIDA, 90, 2000. Ver os seguintes artigos da Revista Brasileira de Política Internacional: Benoni BELLI, O fim da Guerra Fria: algumas implicações para a política externa brasileira, 39 (1), p. 120-131, 1996; Shiguenoli MIYAMOTO, O Brasil e as negociações multilaterais, 43 (1), p. 119-137, 2000; Eiiti SATO, A agenda internacional depois da Guerra Fria: novos temas e novas percepções, 43 (1), p. 138169, 2000; A. F. GRANJA e outros, Acesso aos recursos genéticos, transferência de tecnologia e bioprospecção, 42 (2) p. 81-98, 1999; Marcelo Dias VARELA, Biodiversidade: o Brasil e o quadro internacional, 40 (1), p. 123-141, 1997; José Augusto Lindgren ALVES, O significado político da Conferência de Viena sobre Direitos Humanos, 36 (2), p. 128-135, 1993; Antônio Augusto Cançado TRINDADE, Balanço dos resultados da Conferência Mundial de Direitos Humanos, 36 (2), p. 9-27, 1993; A. VERWEY e outros, A percepção brasileira dos refugiados, 43 (1), p. 183-185, 2000. Luiz Carlos Bresser PEREIRA, A nova centro-esquerda, Instituto Teotônio Vilela, Idéias \& Debates, ${ }^{\circ}$ 24, 1999.

Livro: Proença e Diniz (1998). Artigos dos seguintes autores em Carta Internacional: Geraldo Lesbat CAVAGNARI FILHO, 96, 2001; S. QUINTAMAR e M. Romegialli, 93, 2000; Shiguenoli MIYAMOTO, 89, 2000; Luiz A. P. SOUTO MAIOR, 86, 2000; Rut DIAMINT, 65, 1998. Ver os seguintes artigos da Revista Brasileira de Política Internacional: Odete Maria de OLIVEIRA, A integração bilateral Brasil-Argentina: a tecnololgia nuclear e o Mercosul, 41 (1), p. 5-23, 1998; Amâncio Jorge OLIVEIRA e Janina Onuki, Brasil, Mercosul e a segurança regional, 43 (2), p. 108-129, 2000; Antônio José FERNANDES, O Brasil e o sistema mundial de poderes, 44 (1) p. 94-111, 2001.

Livros: Almeida (1999); Lafer (1999). Artigos dos seguintes autores em Carta Internacional: Fernando KINOSHITA, 93, 2000; Roberto Teixeira da COSTA, 86, 2000; G HUFBAUER e J. J. Schott, 78, 1999; Ricardo Wahrendorff CALDAS, 49, 1997. Ver os seguintes artigos da Revista Brasileira de Política Internacional: Amado Luiz CERVO, Política de comércio exterior e desenvolvimento: a experiência brasileira, 40 (2) p. 5-26, 1997. Maurício Eduardo Cortes COSTA, Estratégias comerciais brasileiras em nível internacional, Debates (Konrad Adenauer-Stiftung) 13, p. 63-69, 1997. Vera THORSTENSEN, As relações econômicas internacionais do Brasil, Debates (Konrad Adenauer-Stiftung), 13, p. 71-98, 1997. Para os dados estatísticos, ver a Série Histórica do Banco Central do Brasil.

Artigo em Carta Internacional: Uziel NOGUEIRA, 61, 1998. Ver os seguintes artigos da Revista Brasileira de Política Internacional: Reinaldo GONÇALVES, Globalização financeira e inserção internacional do Brasil, 39 (1), p. 72-88, 1996; Marcos Antônio Macedo CINTRA, A participação brasileira em negociações multilaterais e regionais sobre serviços financeiros, 42 (1), p. 62-76, 1999; Venício A. de LIMA., Globalização e políticas públicas no Brasil: a 
privatização das comunicações entre 1995 e 1998, 41 (2), 118-138, 1998. Glória MORAES, Telecomunicações: o jogo ainda não acabou! Network. 9 (2), p. 6, 2000.

$6 \quad$ Artigos dos seguintes autores em Carta Internacional: Roberto Teixeira COSTA, 98, 2001; Ronaldo Motta SARDENBERG, 68, 1998; Marcelo JARDIN, 54, 1997; Alexandre Ratsuo UEHARA, 52, 199; Bruno AYLLON, 94-95, 2001. Ver os seguintes artigos da Revista Brasileira de Política Internacional: Frederico Lamego de SOARES, Análise econômica da parceria Brasil-Alemanha no contexto das relações entre o Mercosul e a União Européia, 43 (2), p. 87 107, 2000; Luiz A. P. SOUTO MAIOR, Brasil-Estados Unidos: desafios de um relacionamento assimétrico, 44 (1), p. 55-68, 2001; Graciela Zubelzu de BACIGALUPO, As relações russobrasileiras no pós-Guerra Fria, 43 (2), p. 59-86, 2000); Antônio Carlos LESSA, Os vértices marginais de vocações universais: as relações entre a França e o Brasil de 1945 a nossos dias, 43(2) p. 28-58, 2000; Severino CABRAL, Encontro entre Brasil e China: cooperação para o século XXI, 43 (1), p. 24-42, 2000; Pio PENNA FILHO, África do Sul e Brasil: diplomacia e comércio (1918-2000), 44 (1), p. 69-93, 2001; José Vicente de Sá PIMENTEL, Relações entre o Brasil e a África subsaárica, 43 (1), p. 5-23, 2000. Jacques D’ADESKY, O paradoxo das relações comerciais Brasil-África, Network, 7 (3), p. 1-2, 1998. Cristina Sorenu PECEQUILO, A política externa dos Estados Unidos: fundamentos e perspectivas, Cena Internacional, 2(1), p. 146-170, 2000.

7 Livros: Rapoport (org.) (1995); Cervo e Rapoport (orgs., 1998); Lladós e Guimarães (orgs., (1999); Guimarães (org., 2000); Bernal-Meza (2000); Marcos A. G. de OLIVEIRA, Mercosul e política; São Paulo: LTr, 2001; Mercosul: legislação e textos básicos, Brasília: Senado Federal, 2000. Artigos dos seguintes autores em Carta Internacional: Luiz A. P. SOUTO MAIOR, 93, 2000; A. GREMAUD e M. Bobik, 92, 2000; Fernando MASI, 72, 1999; Rosendo FRAGA, 61, 1998. Ver os seguintes artigos da Revista Brasileira de Política Internacional: Alcides Costa VAZ, Mercosul aos dez anos: crise de crescimento ou perda de indentidade? 44 (1), p. 43-54, 2001; Vera THORSTENSEN, A OMC - Organização Mundial do Comércio e as negociações sobre investimentos e concorrência, 41 (1), p. 56-88, 1998. Raúl BERNAL-MEZA, Argentina: la crisis del desarrollo y de su inserción internacional. São Paulo: Fundação Konrad Adenauer, 2001.

8 Livros: SOARES, (1994); GUIMARÃES (1999). Artigos dos seguintes autores em Carta Internacional: João Clemente Baena SOARES, 51, 1997; G. HUFBAUER e D. Orejas, 99, 2001; Fernando Henrique CARDOSO, 100, 2001; Antônio J. F. SIMÕES, 90, 2000; Flávia de Campos MELLO, 96, 2001; Alberto PFEIFER, 63, 1998; Felipe DE LA BALZE, 91, 2000; Luiz A. P. SOUTO MAIOR, 91, 2000. Reinaldo GONÇALVES, Brasil, integração regional e cooperação internacional, Konrad Adenaur Stiftung, Cadernos Adenauer, nº 2, p. 57-80, 2000.

9 Livro: Saraiva (org., 2001). Artigo em Carta Internacional: Fernando KINOSHITA, 92, 2000; Edmundo FUJITA, 98, 2001. Artigo da Revista Brasileira de Política Internacional: Déborah Barros Leal FARIAS, O Brasil e o CARICOM, 43 (1), p. 43-68, 2000.

10 Dupas (2002).

\section{Bibliografia}

ALBUQUERQUE, José Augusto Guilhon (org.). Sessenta anos de política externa brasileira. São Paulo: USP, 1996. 4 v.

ALMEIDA, Paulo Roberto de. Relações internacionais e política externa do Brasil: dos descobrimentos à globalização. Porto Alegre: Ed. da Universidade, 1998.

ALMEIDA, Paulo Roberto de. O Brasil e o multilateralismo econômico. Porto Alegre: Livraria do Advogado Ed., 1999.

ALMEIDA, Paulo Roberto de. O estudo das relações internacionais do Brasil. São Paulo: Unimarco Editora, 1999. 
ALVES, J. A. Lindgren. Os direitos humanos como tema global. São Paulo: Perspectiva, 1994.

ALVES, José Augusto Lindren. Relações internacionais e temas sociais. A década das conferências. Brasília: IBRI, 2001.

BANDEIRA, Moniz.. Brasil-Estados Unidos; a rivalidade emergente. Rio de Janeiro: Civilização Brasileira, 1990.

BANDEIRA, Moniz. Estado nacional e política internacional na América Latina (1930-1992). São Paulo: Ensaio, 1993.

BANDEIRA, Moniz.. O milagre alemão e o desenvolvimento brasileiro. São Paulo: Ensaio, 1994.

BANDEIRA, Moniz.. De Martí a Fidel; a revolução cubana e a América Latina. Rio de Janeiro: Civilização Brasileira, 1998

BARRETO, Fernando de Mello.Os sucessores do Barão.1912-1964. Relações exteriores do Brasil. São Paulo: Paz e Terra, 2001.

BERNAL-MEZA, Raúl. Sistema Mundial y Mercosur: globalización, regionalismo y políticas exteriores comparadas. Buenos Aires: Grupo Editor, 2000.

CERVO, Amado Luiz. 1994. As relações históricas entre o Brasil e a Itália; o papel da diplomacia. Brasília: Ed. Univ. de Brasília; São Paulo: Instituto Italiano de Cultura, Tradução para o italiano: Le relazioni diplomatiche fra Italia e Brasile dal 1861 ad oggi. Torino: Ed. Agnelli, 1992.

CERVO, Amado Luiz..As relações internacionais da América Latina; velhos e novos paradigmas. Brasília: IBRI, 2001

CERVO, Amado Luiz (org.). O desafio internacional; a política exterior do Brasil de 1930 a nossos dias. Brasília: Ed. da Univ. de Brasília, 1994.

CERVO, Amado Luiz \& BUENO, Clodoaldo. História da política exterior do Brasil. Brasília: EdUnB, 2002.

CERVO, Amado Luiz \& RAPOPORT, Mario. (orgs.) História do Cone Sul. Rio de Janeiro, Revan; Brasília: Ed. da Univ. de Brasília, 1998.

CERVO, Amado Luiz \& MAGALHÃES, José Calvet de.. Depois das Caravelas: as relações entre Portugal e Brasil, 1808-2000. Brasília: Ed. da Univ. de Brasília, 2000.

DANESE, Sérgio F. Diplomacia presidencial; história e crítica. Rio de Janeiro: Topbooks, 1999.

DUPAS, Gilberto. Hegemonia, Estado e governabilidade. Perplexidade e alternativas no centro e na periferia. São Paulo: SENAC, 2002.

FONSECA JÚNIOR., Gelson. A legitimidade e outras questões internacionais. São Paulo: Paz e Terra, 1998.

GUIMARÃES, Samuel Pinheiro. Quinhentos anos de periferia; uma contribuição ao estudo da política internacional. Porto Alegre: Ed. da Universidade, 1999.

GUIMARÃES, Samuel Pinheiro (org.) Argentina: visões brasileiras. Brasília: FUNAG, 2000.

GUIMARÃES, Samuel Pinheiro (org.) ALCA e Mecosul: riscos e oportunidades para o Brasil, Brasília: FUNAG, 1999.

LAFER, Celso. Comércio, desarmamento, direitos humanos. São Paulo: Paz e Terra, 1999

LAMPREIA, Luiz Felipe. 1999. Diplomacia brasileira: palavras, contextos e razões. Rio de Janeiro, Lacerda Ed., p. 9-13.

LESSA, Antônio Carlos Moraes. A parceria bloqueada: as relações entre França e Brasil, 19452000. Univ. de Brasília. Tese de Doutorado, 2000

LLADÓS, José M. \& Guimarães, Samuel P. Perspectivas: Brasil y Argentina. Buenos Aires: Cari, 1999.

LOHBAUER, Christian. Brasil-Alemanha: fases de uma parceria (1964-1999). São Paulo: Edusp, 2000 ,

MIYAMOTO, Shiguenoli. Geopolítica e poder no Brasil. Campinas: Papirus, 1995

PENNA FILHO, Pio. Do pragmatismo consciente à parceria estratégica: as relações entre Brasil e África do Sul (1918-2000). Univ. de Brasília. Tese de Doutorado, 2001. 
RAPOPORT, Mario (org.). Argentina y Brasil en el Mercosur: políticas comunes y alianzas regionales. Buenos Aires: Grupo Editor Latino americano, 1995.

SARAIVA, José Flávio Sombra. O lugar da África: a dimensão atlântica da política exterior do Brasil. Brasília: Ed. Univ. de Brasília, 1996.

SARAIVA José Flávio Sombra (org.). Relações internacionais. Dois séculos de História. Brasília: IBRI, 2001.

SARAIVA, José Flávio Sombra (org.). Comunidade dos Países de Língua Portuguesa (CPLP): solidariedade e ação política. Brasília: IBRI, 2001.

SOARES, João Clemente Baena. Síntese de uma gestão, 1984-1994. OEA, 1994.

TRINDADE, Antônio Augusto Cançado. A proteção internacional dos direitos humanos e o Brasil. Brasília, EdUnB. 1998.

Resumo

Desde 1990, particularmente durante os dois mandatos de Fernando Henrique Cardoso, as relações internacionais do Brasil foram caracterizadas por ausência de estratégia de inserção no mundo da interdependência global, visto que a abertura foi eleita como ideologia de mudança. O Brasil empenhou-se junto aos órgãos multilaterais para estabelecer um ordenamento mundial nas áreas do comércio, meio ambiente, finanças e segurança. Atribuiu importância ao processo de integração do Cone Sul. As relações internacionais apresentaram resultados medíocres no comércio exterior, induziram forte dependência financeira e abalaram o núcleo nacional da economia.

\section{Abstract}

Since 1990, particularly during the two administrations of Fernando Henrique Cardoso, the Brazilian's international relations were characterized by the absence of an insertion strategy in a world of global interdependence, when the opening was chosen as the ideology of change. Brazil, together with the multilateral organizations, worked on establishing a world order on trade, environment, finances and security sectors. It attributed importance to the process of integration of the South Cone. The international relations presented mediocre results on international trade, induced to strong financial dependence and affected the national nucleus of the economy.

Palavras-chave: Brasil; Política exterior; Relações internacionais. Key words: Brazil; Foreign Policy; International Relations. 